\title{
深層混合処理工法における計測施工に関する研究
}

\section{STUDY ON THE MONITORING IN DEEP MIXING METHOD}

\author{
畠 昭治郎*・檜 垣 義 雄**.青 井 実***・芦田恵 樹**** \\ By Shojiro HATA, Yoshio HIGAKI, Minor" AOI and Shigeki ASHIDA
}

\begin{abstract}
DMM (Deep Mixing Method) is an effective soil improvement method. In this study, the indoor test was practiced with a model apparatus of mixing machine and the mixing mechanism was considered to investigate the relationship between soil properties and the resisting moment, penetrating resistance on mixing blade of mixing machine. From this investigation, the method was proposed to estimate the kind and the properties of original ground soil.

The field test was practiced with actual DM-machine to ascertain the results of the indoor test. Moreover, two methods, the measurement of density and water contents with Radio-Isotope, and the work-done analysis, were proposed and verfied to appraise the quality of treated soil in field. From these results, the possibility for electro-mechanical control in DMM is considered.
\end{abstract}

Keywords : deep mixing method, soil improvement, monitoring, field experiment

\section{1.はじめに}

深層混合処理工法は, 軟弱地盤内に石灰系, セメント 系の改良材をスラリー状での圧送または粉体のままでの 空気搬送により添加し，原地盤と均一に覞汼混合して地 盤内に強度の高い安定処理土を形成し, 軟弱地盤を改良 する工法である ${ }^{1)}$. 本工法は他の軟弱地盤改良工法に比 べ高い強度に改良できることや，周辺の構造物に対する 影響や騒音, 振動, 大気污染といった建設公害がきわめ て少ないことなど多くの利点を有している．そのため隣 接施工など特殊用途に多く用いられてきている. 反面工 費が高くなるため, 一般的な用途では敬遠されがちであ る.これは 1 つに設計や施工法に関して未完成の部分が 多く, 必要以上に安全側に施工を行わなければならない ことが原因となっていると考えられる2!.

施工法の未完成な部分の 1 つしして, 本工法が他の軟 弱地盤改良工法と同様に地盤内で施工されるため, 施工 状況を直接みることはできず, 施工精度の判断は計测值

* 正会員 工博 京都大学教授 工学部土木工学科 ( ( 606 京都市左京区吉田本町)

** 正会員 京都大学技官 工学部土木工学科 (同上)

***（株）神戸製銅所 （ ( 651 神戸市中央区脇浜町 1-3-18)

**** 正会員 工修 (株) 神戸製鋼所 (同上)
に頼らざるを得ないにもかかわらず，現状の施工管理は 施工中の計測値が有効に用いられていないことが挙げら れる．たとえば施工は，本工法における強度の発現が原 地盤の土性に大きく影響されるにもかかわらず，わずか 数本の事前サンプリングによる調査結果のみに基づいて 行われており，施工中の計測値は改良効果に対して有効 に用いられていない. すなわち局所的な土性の変化は考 慮せず, 施工設定条件（覞汼回転数, 引き抜き速さ, 改 良材供給量なよ゙)を一定に保つように施工されているが, 改良体の品質にばらつきが生じては, いくら均一な施工 を行っても意味がない。このように本工法における品質 の向上には，施工中の計測值を用いて，局所的な土性の 変化に対処し得る施工を行うことが有効である. また改 良体の品質の評価は, 施工の 1 か月後に改良体が完成し た後に行われるコアサンプリングによってなされてお り，施工中の計測值はまったく用いられていない.

本研究では, 摫找翼にかかる抵抗モーメントと原地盤 の強度との関係に着目し，裀汼翼貫入の際に原地盤の土 性を的確に把握する方法について模型を用いた実験を 行って検討した. さらに模型実験の結果について実機に よる現場実験を行い, その内容を検証した。これらの結 果に基づき，実際の施工において摜汼翼貫入の際に原地 盤の土性を把握する方法を提案した. 今後これを用いて 
引抜時に局所的な土性の変化に対処し得る引拔吐出によ る改良施工を行うことができるようにするものである.

また施工中の計測値を用いた改良体の施工品質を仕事 率で表示する方法を提案し ${ }^{3)}$, 現場実験においてその妥 当性を検討した。これによって施工直後に，全改良体に 対して品質の評価を行うことができる.

以上の上うに本研究は施工中の計測值を有効に用いて 適切な計測施工と十分な施工品質の確認を可能にするも ので，これにより本工法の機械的，電気的自動制御化を めざすものである．またこれはただ単に工費を安くおさ えるだけでなく，本工法が種々の用途に用いられること で, 多くの付加価值を生む可能性を含んでいる.

\section{2. 㨨找翼による地盤状態の把握}

\section{（1）室内模型実験 ${ }^{4) ~ 6) ~}$}

\section{a) 実験試料および実験装置}

実験は砂および粘土に対して行い，砂としては小豆島 砂を，粘土としては深草粘土を用いた。 それぞれの試料 の特性を Table 1 に, また粒径加積曲線を Fig. 1 に示す. なお深草粘土については，3 種の圧密段階において実験 を行い, それぞれ梁草粘土 I (圧密荷重 $1 \mathrm{kgf} / \mathrm{cm}^{2}$ ), 同 II $\left(2 \mathrm{kgf} / \mathrm{cm}^{2}\right)$ ，同 III $\left(4 \mathrm{kgf} / \mathrm{cm}^{2}\right)$ とした.

Table 1 Soil Index Properties of Syodoshima Sand and Fukakusa Clay.

\begin{tabular}{|c|c|c|c|c|}
\hline & $\begin{array}{r}\text { Syodoshima } \\
\text { Sand }\end{array}$ & \multicolumn{3}{|c|}{$\begin{array}{l}\text { Fukakusa } \\
\qquad \text { Clay }\end{array}$} \\
\hline \multirow[t]{3}{*}{$\begin{array}{l}\text { Specific Gravity } \\
\text { Soil Classification } \\
\text { Liquid Limit } \\
\text { Plastic Limit }(\boldsymbol{\%}) \\
\text { Plasticity Index }\end{array}$} & \multirow[t]{3}{*}{$\begin{array}{r}2.65 \\
S P_{u}\end{array}$} & \multicolumn{3}{|c|}{$\begin{array}{l}2.69 \\
\mathrm{MH} \\
52.4 \\
31.4 \\
21.0\end{array}$} \\
\hline & & \multicolumn{3}{|c|}{ Consol idation Stage } \\
\hline & & I & II & III \\
\hline Unit We ight $\left(\mathrm{gf} / \mathrm{cm}^{3}\right)$ & 1.74 & 1.77 & 1.81 & 1.83 \\
\hline Water Contents & 46.4 & 46.0 & 37.5 & 32.0 \\
\hline Void Ratio & 1.23 & 1.23 & 1.01 & 0.86 \\
\hline $\begin{array}{l}\text { Consistency Index } \\
\text { Unconfined Compression }\end{array}$ & & 0.30 & 0.71 & 0.97 \\
\hline St reng th $\quad\left(\mathrm{kgf} / \mathrm{cm}^{2}\right)$ & & 0.367 & 0.638 & 0.834 \\
\hline
\end{tabular}

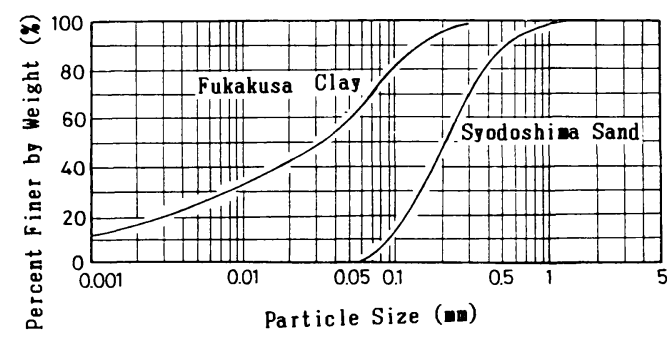

Fig. 1 Grain Size Accumulation Curve of Syodoshima Sand and Fukakusa Clay.
実験に用いた装置の概要を Fig. 2 に示す．摫汼軸の回 転は油圧モータにより, 昇降は軸を含め $1.27 \mathrm{tf}$ (フリ クションロスは除く) の自重をもつ貫入部分をワイヤー ロープで制御することにより行った。

また，実験に用いた摫挥翼の形状を Fig. 3 に示す.

b) 実験内容

砂および粘土のそれぞれを均一に入れた土槽内に摫汼 翼を貫入して，その際に㹂汼翼にかかる抵抗モーメント と砂および粘土のコーン指数との関係について検討し た。

実験は, $1 \mathrm{~m}$ 当たりの翼摫汼数（羽根切り回数）を 20 , 30，40，50，60，70 rev/m に設定，貫入速さを $8 \sim 20$ $\mathrm{mm} / \mathrm{s}$ まで $2 \mathrm{~mm} / \mathrm{s}$ で等間隔に 7 点とり，そのとき決定 される回転数 4.8 30.0 rpm の組合せの中から実験時の 条件を設定，翼にかかる抵抗モーメントへのそれぞれの 影響を調べた。

コーン指数はポータブル試験機（先端角 $30^{\circ}$, 底面直 径 $30 \mathrm{~mm}$ ）を用いた単純コーン貫入試験により求め, 抵抗モーメントはスリップリングを利用したトルク計を 用いて電気的に検出した。

c) 実験結果
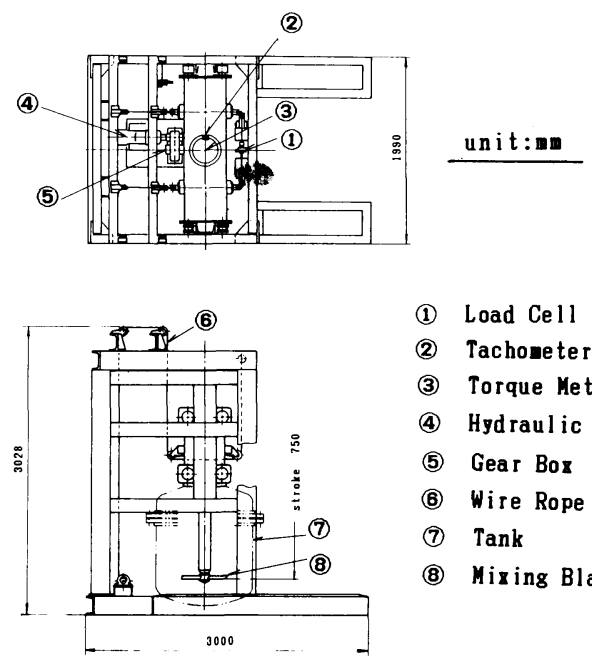

(1) Load Cell

(2) Tachometer

(3) Torque Meter

(4) Hydraulic Motor

(5) Gear Box

(6) Wire Rope

(7) Tank

(8) Mixing Blade

Fig. 2 Profile of Model Test Apparatus of Mixing Machine.

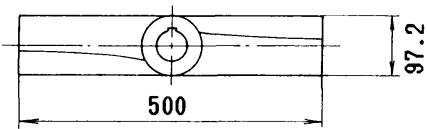

unit: :
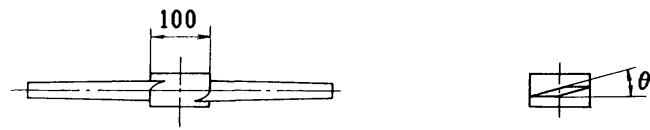

Fig. 3 Mixing Blade. 


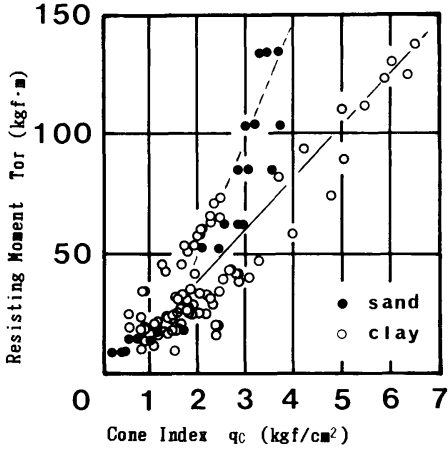

Fig. 4 Relation of Resisting Moment to Cone Index obtained from the Model Test.

実験によって得られた抵抗モーメントとコーン指数の 関係の一例を Fig. 4 に示す。ここで回転数は $15 \mathrm{rpm}$, 貫入速さは $10 \mathrm{~mm} / \mathrm{s}$ である.これをもとに，砂および 粘土のそれぞれについて抵抗モーメントとコーン指数の 関係を比例関係としてとらえると，試料の違いによる影 響は比例係数や切片の相違によって現われることがわか る.なお粘土については, 試料 I，II，IIIとも，同じ傾 向を示したので $1 つ に$ 合わせて扱った.

さらにこれ之同時に回転数や貫入速さの違いによる影 響を検討したが，有意な差異を認めるにはいたらなかっ た。

\section{（2）現場検証実験}

\section{a) 事前 調 査}

今回の現場実験は, 新潟県南魚沼郡六日町西泉田地先 の伊田川左岸で，昭和 60 年 7 8 月に行った．実験区域 の付近において行われたシンウォールサンプリングによ り得られた柱状図を，同一地点で行われた標準貫入陚験 の結果と合わせて Fig. 5 に示す。 また同時にサンプリン グによる不挸乱試料の採取位置も示す。

不摫乱試料により得られた各種土質定数を Table 2 に, 粒径加積曲線を Fig. 6 に示す ${ }^{7)}$.

以上に示したような一般的な土質調查に加えて, 実験 区域内 4 点において三成分コーン貫入試験を行った。こ れにより本地点の土性を表わすコーン指数, 周面摩擦お よび間隙水圧の深さ方向に連続な值が得られた。計測結 果の一例を Fig. 7 に示す ${ }^{8)}$.

b) 実験区域

全実験区域の平面図を Fig. 8 に示す．丸印は改良体の 位置を示し，丸の大きさは改良断面を表わす。また横の 数字はその改良体番号である. 室内模型実験の検証は改 良体 1 6 および 20 25 の 12 本において行った。 また C-2 5 は三成分コーンの計測地点を, RI-A，RI-B, RI-C は，後述の RI による密度・水分量計測の計測点 を示す．RI-A が事前計測， RI-B および RI-C は改良

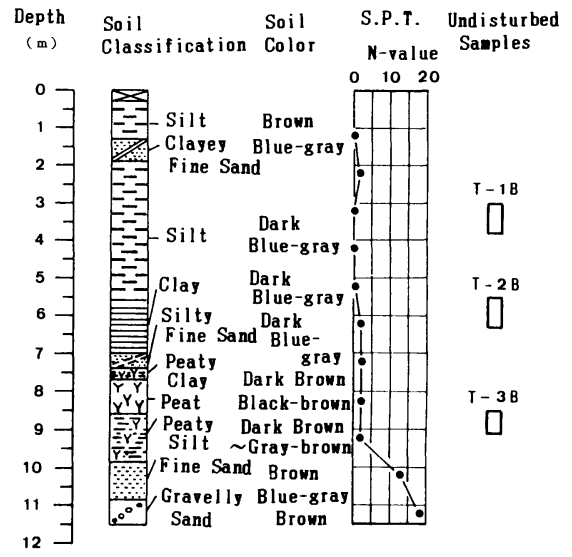

Fig. 5 Boring Log of the Test Field.

Table 2 Index Properties of the Field Soil

\begin{tabular}{|c|c|c|c|c|c|c|}
\hline \multirow{2}{*}{$\begin{array}{l}\text { Boring Number } \\
\text { Depth of Undisturbed Samples }\end{array}$} & \multicolumn{3}{|c|}{ B -1} & \multicolumn{3}{|c|}{ B -2} \\
\hline & $3 \mathrm{~m}$ & $6 \mathrm{~m}$ & $9 \mathrm{~m}$ & $3 \mathrm{~m}$ & $6 \mathrm{~m}$ & $9 \mathrm{~m}$ \\
\hline Specific Gravity G & 2.715 & 2.660 & 2.573 & 2.672 & 2.657 & 2.649 \\
\hline Soil Classification & Ma & ML & $\mathrm{CH}$ & $\mathrm{CH}$ & $\mathrm{CH}$ & $\mathrm{CH}$ \\
\hline - Ignition Loss & 0 & 1.980 & 6.217 & 1.417 & 2.121 & 2.500 \\
\hline Liquid Lisit & 42 & 49 & 67 & 58 & $5 ?$ & 53 \\
\hline Plastic Linit & 29 & 31 & 35 & 29 & 32 & 29 \\
\hline -Plasticity Indez $\quad I_{P}$ & 13 & 18 & 32 & 29 & 25 & 24 \\
\hline - Activity & 0.59 & 0.58 & 1.19 & 0.88 & 0.74 & 0.75 \\
\hline Water Contents & 57.3 & 60.2 & 58.1 & 53.6 & 56.7 & 49.6 \\
\hline 'Water Contents(mean) $\mathbf{w}_{n}{ }^{\prime}(\mathbf{y})$ & 54.7 & 61.3 & 62.2 & 52.7 & 52.0 & 63.2 \\
\hline -Consistency Inder $I_{C}$ & -0.98 & -0.68 & 0.15 & 0.18 & 0.20 & -0.43 \\
\hline Unit Weight & 1.690 & 1.603 & 1.063 & 1.693 & 1.742 & 1.670 \\
\hline $\begin{array}{l}\text { - Void Ratio e } \\
\text { Unconf ined Compression }\end{array}$ & 1.485 & 1.631 & 1.600 & 1.408 & 1.382 & 1.674 \\
\hline $\mathrm{q}_{\mathrm{u}}\left(\mathrm{kgf} / \mathrm{cm}^{2}\right)$ & 0.266 & 0.471 & 0.856 & 0.406 & 0.519 & 0.809 \\
\hline Failure Strain $\quad \epsilon_{1}(\boldsymbol{X})$ & 12.9 & 4.2 & 9.0 & 12.7 & 6.1 & 6.8 \\
\hline Modulus of Deformation $E_{s 0}$ & 15.1 & 25.1 & 27.5 & 17.7 & 27.4 & 25.3 \\
\hline
\end{tabular}

* : Calculated Value

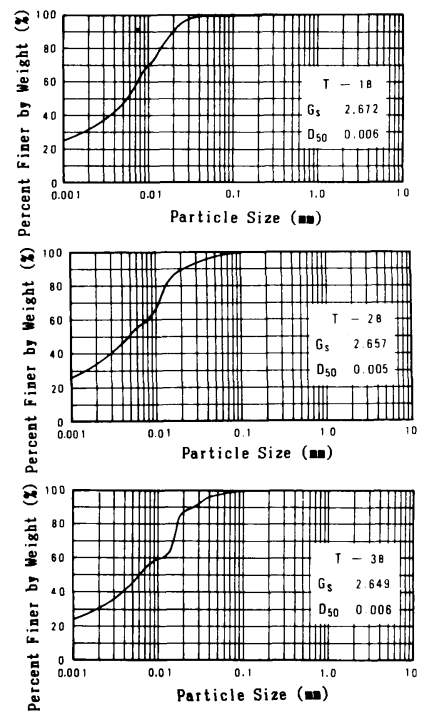

Fig. 6 Grain Size Accumulation Curve of the Field Soil. 


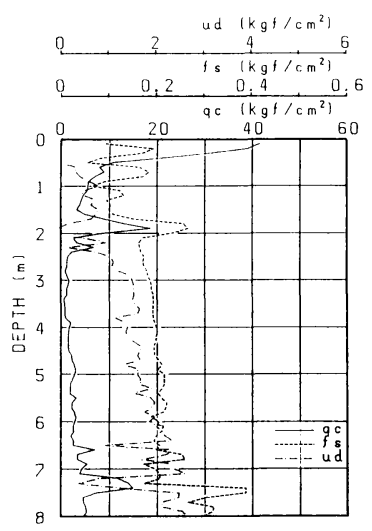
qc : Cone Index
fs : Skin Friction
ud : Pore Water
Pressure

Fig. 7 The Results of Three-components Cone Penetration Test.

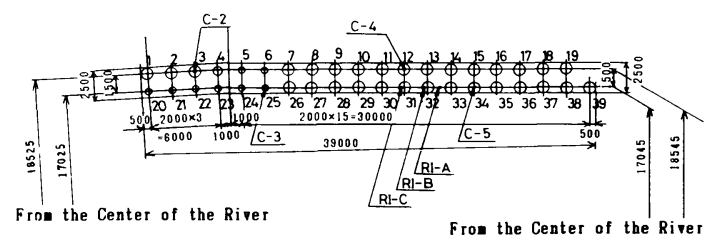

Fig. 8 Test Field.

後の計測点である.

c) 実験装置

今回の実験には, 自走式単軸型の粉体噴射摫拌工法専 用施工装置を用いた。 その本体の概要を Fig. 9 に示す. また実験は室内模型実験とほぼ同型で翼径 $500 \mathrm{~mm}$ の摫 找翼を用い，その形状を Fig. 10 に示す。また，実機で 一般的に用いられる翼の多くが翼径 $1000 \mathrm{~mm}$ であるこ とを考虑し，翼径の影響を検討するため，翼径 1000 $\mathrm{mm}$ および $750 \mathrm{~mm}$ の翼を用いた実験も行った。

\section{d) 実験結果}

実験により得られたコーン指数と抵抗モーメントとの 関係を翼径 $500 \mathrm{~mm}$ の翼について Fig. 11 に示す。これ をみると，現場実験においても室内模型実験と同様に， コーン指数と抵抗モーメントがそれぞれの土について比 例しているととらえてさしつかえないことがわかる.ま た土の種類によってその比例係数および切片が変化して いることも明確に表わされている。ただ比例係数につい ては, 室内模型実験と現場実験で砂と粘土の関係が逆転 しているが，これは室内模型実験の試料が現場に比へ， わずか $1 \mathrm{~m}^{3}$ 程度の狭い範囲（実験土槽内）に拘束され ていたなどの要因が考えられる.

このように室内模型実験で考えたコーン指数と抵抗 モーメントの比例関係は，現場においても保たれること が実証された。また翼径 $1000 \mathrm{~mm}, 750 \mathrm{~mm}$ の翼および 実際の噴射摫汼改良に用いる翼についても同様の結果が 得られた。

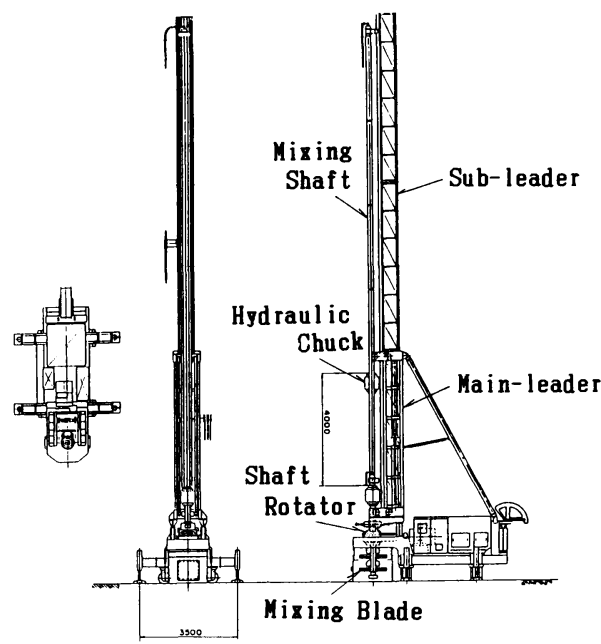

Fig. 9 Profile of Actual DM-machine.
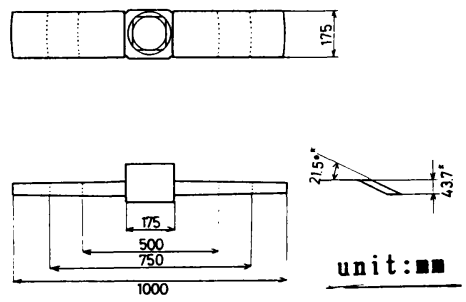

Fig. 10 Mixing Blade of DM-machine.

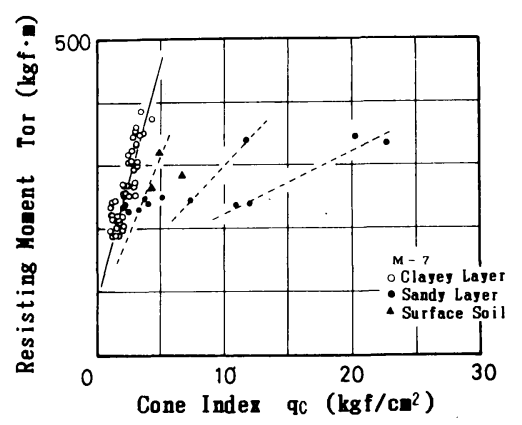

Fig. 11 Relation of Resisting Moment to Cone Index obtained from the Field Test.

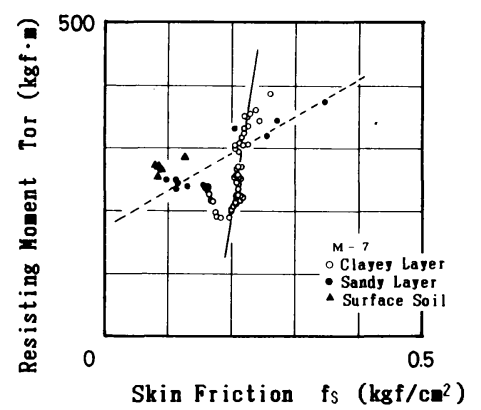

Fig. 12 Relation of Resisting Moment to Skin Friction obtained from the Field Test. 
室内模型実験で得られたコーン指数と抵抗モーメント 之の関係以外に，周面摩擦と抵抗モーメントにも同様の 関係があることが現場実験において新たにわかった．実 験により得られたこの関係を Fig. 12 に示す。それぞれ の土について周面摩擦と抵抗モーメントが比例し，また 土の種類によってその比例係数と切片が変化することが よくわかる.

\section{（3）翼䢁翼にかかる抵抗力の解釈}

a) 䚋汼翼にかかる抵抗力

簡単のため翼の片方のみについて検討する．また翼の 径方向に分布してかかる抵抗力を集中荷重として考え, その着力点は半径の $1 / 2$ の点とする.

着力点の断面において，䚇汼翼にかかる抵抗力を Fig.13のように考える.ここに刃面の水平となす角を $\theta$, 進行方向を $\varphi$ とし, 刃面の面積を $A$, 進行方向に対 する投影面積を $S$ とする. また，刚面にかかる抵抗力 を刃面に垂直方向に $\sigma \cdot A$, 刃面にそった方向に $\tau \cdot A$ とし，刃先にかかる抵抗力を $H$ ，これらを合わせた全 体の抵抗力を $F$ とする. $H$ と $F$ についてはその刃面 方向の抵抗力をそれぞれ $H_{\theta}, F_{\theta}$ とし, 進行方向成分は $H_{\varphi}, F_{\varphi}$ とする.

b) 筧汼翼にかかる抵抗力と周面摩擦との関係

周面摩擦は，計測面にそって土が動くときにその面に かかる単位面積当たりの力である．これを刃面にあては めると

$$
\tau=a \cdot f_{s} \cdots
$$

と考えることができる． $a$ は比例定数である．そこで㩖 拌翼にかかる抵抗力の刃面方向の成分について考えると 次式が得られる.

$$
\begin{aligned}
F_{\theta} & =H_{\theta}+\tau \cdot A \\
& =H_{\theta}+a \cdot f_{s} \cdot A
\end{aligned}
$$

実際のデー夕を用いて次のように $F_{\boldsymbol{\theta}}$ を計算し， $F_{\boldsymbol{\theta}}$ と $f_{s} \cdot A$ の関係を示すと Fig. 14 のようになる.

$$
F_{\theta}=F \cos (\theta-\beta)
$$

ただし $F$ は摫拌翼にかかる抵抗力, $\beta$ はその抵抗力の かかる方向と水平とのなす角で以下のように表わされ る.

$$
\begin{aligned}
& F=\sqrt{(\text { Tor } / r)^{2}+(\text { Res } / 2)^{2}} \\
& \beta=\tan ^{-1} \frac{\operatorname{Res} / 2}{\text { Tor } / r}
\end{aligned}
$$

ここに Tor は抵抗モーメント, Res は摫汼翼の貫入抵 抗で, $r$ は翼径の $1 / 2$ である.

この図をみると，それぞれの土について $f_{s} \cdot A$ と $F_{\theta}$ が比例し, 式（2）がうまく表わされていることがわか る. また比例定数 $a$ および切片 $H_{\theta}$ については, 砂質土 と粘性土の間で, 相違がみられる.

c）筧汼翼にかかる抵抗力とコーン指数の関係

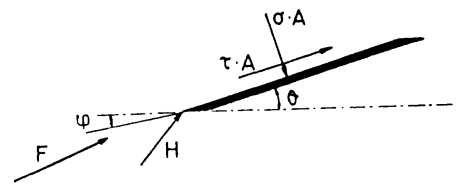

F : Resistance acted on the Blade

$H$ : Resistance acted on the Tip of the Blade

$\sigma \cdot A$ : Resistance acted on the Surface of the Blade (vertical to the surface)

$\tau$ - A : Resistance acted on the Surface of the Blade (parallel to the surface)

$\varphi$ : Moring Direction

$\theta$ : Clearance Angle

Fig. 13 Resistance acted on the Blade.

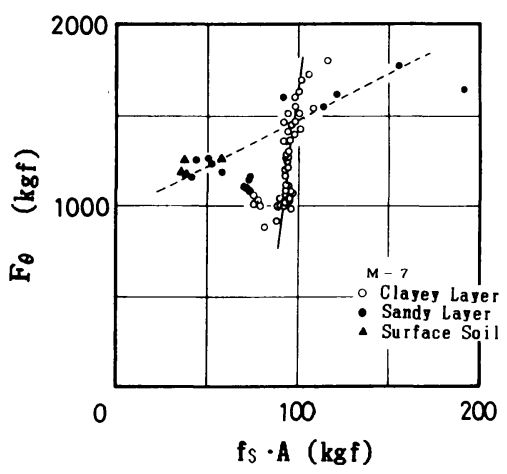

Fig. 14 Relation of $F_{\theta}$ to $f_{s} \cdot A$.

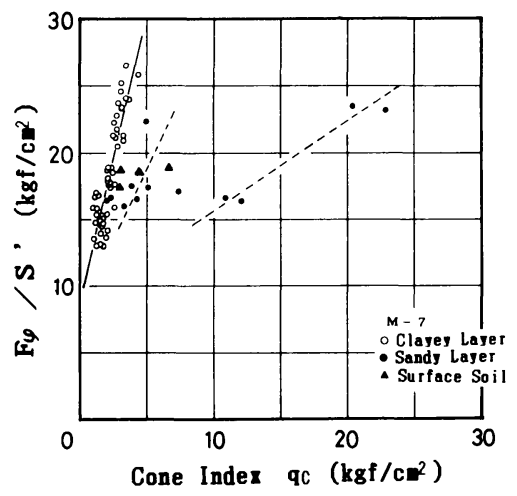

Fig. 15 Relation of $F_{\theta} / S$ ' to Cone Index.

コーン指数は, コーン進行方向に対してかかる抵抗力 をこの投影面積で割った值である．この考えに基づき，

擋挥翼についても進行方向にかかる抵抗力 $F_{\Phi}$ をその投 影面積 $S$ で割った値をとりあげ, コーン指数との関係 について検討した.

㩇汼翼にかかる抵抗力 $F_{\boldsymbol{\phi}}$ は,

$F_{\varphi}=H_{\varphi}+\sigma \cdot A \sin (\theta-\varphi)+\tau \cdot A \cos (\theta-\varphi)$

のように表わされる．また投影面積については䚋汼の繰 り返しによる強度の低下を考虑し，1度摫汼した部分を 
2 度目あるいはそれ以上に掘削する分には, 実験の結果 に基づき, 全層にわたって $2 / 3$ を掛けて計算し， $S$ と してこれを用いた。

ここで $F_{\varphi} / S$ 'とコーン指数との関係を Fig. 15 に示 す.それぞれの土についてコーン指数と $F_{\phi} / S^{\prime}$ が比例 していることがょくわかる．この関係を式で表わすと次 のようになる.

$F_{\varphi} / S^{\prime}=a^{\prime} \cdot q_{c}+b$

ここに $a^{\prime}, b$ は定数であり,

$b=\{\sigma \sin (\theta-\varphi)+\tau \cos (\theta-\varphi)\} \cdot A / S^{\prime}$

である。

\section{（4）瀷找翼による原地盤の把握方法}

以上により，摫抖翼にかかる抵抗力と原地盤のコーン 指数や周面摩擦の関係が明らかになった。またこれらの 関係に及ぼす土の種類の影響も，2 種類ではあるが考慮 することができた。

実際に施工管理にこれを用いる方法としては，まず現 場において二成分コーン貫入試験（コーン指数, 周面摩 擦）を数地点で行うか，もしくはコアサンプリングによ り土の種類を確認した後，同一地点に摫汼翼を貫入して 抵抗モーメントおよび瀶汼翼の貫入抵抗を計測し，摫汼 翼にかかる抵抗力を計算して，式（2），（７）における 比例係数を求める.これを用いれば， 1 本 1 本の改良施 工に対して次に挙げる 4 項目のうちどちらか 2 項目を計 測すれば, 残りの 2 項目を推定することができ, 的確な 土性の把握が可能となる.

(1) 筧汼翼貫入時にかかる抵抗力

(2) 原地盤のコーン指数

(3) 原地盤の周面摩擦

(4) 原地盤の土の種類

ところで今回述べた方法は，サンプリングあるいは コーン貫入試験と㹂汼翼貫入の際の計測値の併用により 原地盤の状態を把握するものであり, 本研究の本来の目 的である，摫拌翼から得られる計測值のみによる地盤内 の状態の把握を可能にすることはできなかった．今後本 研究をさらに進めこの方法を確立することは, 深層混合 処理工法における的確な計測施工を可能にしていくうえ で, 重要な課題である.

なお，摫汼翼による原地盤の把握方法として現在，今 回述べた方法以外に，靦汼翼を回転させずに貫入し，そ のときに翼にかかる荷重と変位の関係などから単位変位 当たりの荷重変化率や単位時間当たりの荷重変化率, 摫 汼翼の貫入速さを求め,これらを用いて原地盤の土の種 類を判別する方法 ${ }^{6}$ を，また摫拌翼貫入の際に翼にかか る抵抗力の水平となす角を考慮することにより，粘着力 の違いによる原地盤の土の種類の判別を行う方法" ${ }^{9}$ を検 討中である.
（5）本工法におけるコーン指数, 周面摩擦計測の意 義

今回の実験で,一般的な土質調查のほかにコーン指数, 周面摩擦の計測を行った。 そこでこれらの計測值を用い Schmertmannによる土質分類を行い，本工法への適用 性について検討した。

コーン貫入試験は力学試験であるため，土質分類には あまり広く用いられていない。しかし，コーン貫入試験 で土質分類を行えば，深さ方向に連続な土質データが得 られるだけでなく, サンプリングより簡単にまた多くの 地点においてデータが得られ, 本工法において各土質に 対する適切な施工を行ううえでかなり有効なものとなる ことが考えられる.

今回の実験により得られた計測値を用いて, Schmertmann による土質分類を行った一例を Fig. 16 に 示す ${ }^{10)}$. なおこの図に記入した点の各層の分類は現場で 行った 4 地点の事前調査に基づいたものである.これを みると，各層が明確に判別できることがわかる．またサ ンドマットおよび表土は改良の対象外なので除外する が，砂質層と粘性土層についてそれぞれ改良後の強度発 現状況をボーリングコアの一軸圧縮強度によってみてみ ると，粘性土層ではまずまずの改良強度が得られたのに 対し，砂質層については過剩に強度がでていたりあるい はボーリングコアが切れたりしており，適切な改良が行 えなかったことがわかった。これは改良材が砂質層に不 向きであったことや砂質層に適した摜拌を行うことがで きていなかったことが原因と考えられる。いずれにせよ 今回行った Schmertmannによる土質分類が，改良後の 強度発現の状況を明確に反映することがわかった.

以上のように，施工前のコーン貫入試験による Schmertmann の土質分類の適用が，精度のよい施工を 行うための適切な施工管理に有効であることがわかつ た。またこれは, 今後摫汼翼によるコーン指数, 周面摩 擦の推定方法を検討していくことが本工法にとって十分 に有効なものであることも示している.

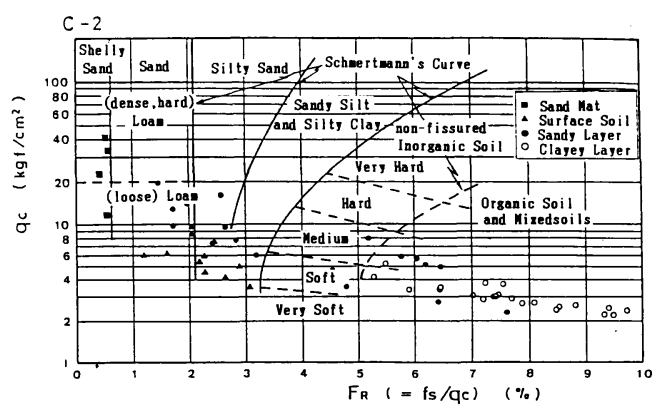

Fig. 16 Soil Classification by Schmertmann. 


\section{3. 施工中の計測値を用いた改良体の品質評価}

\section{（1） RIによる密度・水分量計測の導入 ${ }^{111}$}

施工後の改良体の品質評価は現状では事後ボーリング による一軸圧縮強度試験に頼らざるを得ない。この方法 は改良直後の評価が不可能なうえ，ボーリングコアのと れない部分については試験ができず評価が行えない，ま たボーリングによって改良体に乱れが生じてしまうなど 多くの欠点を有している．そこで施工直後の原位置での 品質評価の方法として，RIによる密度・水分量計測の 導入を提案する.

今回の計測には線源として密度計測に ${ }^{137} \mathrm{Cs}$ を $10 \mathrm{~m}$ $\mathrm{Ci}$ ，水分量計測に ${ }^{252} \mathrm{Cf}$ を $50 \mu \mathrm{Ci}$ 用い，検出管には密度 計測において GM 管を，水分量計測において ${ }^{2} \mathrm{He}$ 比例 係数管を用いた．測定方法は挿入型検層計を用いた乱方 式である12).

この方法は改良材搬送による水や空気の混入状況を評 価し，改良体の均一性を検討するものである．今回の現 場実験は粉体噴射摫拌工法であるため, RI による密度・ 水分量計測により改良体に残された空隙の評価について 検討した．改良体に対する計測結果を，原地盤の計測結 果と合わせて Fig. 17 に示す ${ }^{12)}$. 記号 RI-A が原地盤, RI-B および RI-C が改良体に対する計測結果である。 なお計測地点については前出の実験区域平面図（Fig.8） を参照されたい.

まず改良体を原地盤と比較すると, 密度 (単位体積重 量）がやや大きくなり，含水量および含水比は小さく， 飽和度も低下していることがわかる．これは改良材の混 入をよく表わしている，ところが空隙率については改良 材の混入よりも，搬送空気の混入により大きくなってい る。このことは粉体噴射靦汼工法において大きな問題の 1 つだろうが, 特に空隙が均等に散らず 1 か所に集中し た場合には強度の面からも大きな問題となる。 そこで改 良体において計測された空隙率をみると, RI-Bについ て深さ 6 7 $\mathrm{m}$ あたりに極端に空隙の大きな部分がある ことがわかる．これはそのすぐ上に含水量の大きな層が 存在しているため，搬送空気が回収されずに改良体内に 残されてしまったことを示しており，この部分は強度的 にかなりの問題を残すと考えられる，RI-C の計測結果 については深さ方向にほぼ一様な空隙率が得られ，均質 な改良体が得られたことを表わしている.

以上のように改良体に対する RIによる密度・水分量 計測が，改良体内に残された空隙や水分量を施工直後に 比較的短時間で評価し，改良体の均質性すなわち施工精 度を判定する有効な方法であることがわかった。ただ本 工法が強度管理を主としている以上，この方法を実際に 施工管理に用いていくためには，RIによる計測結果と
R I - A

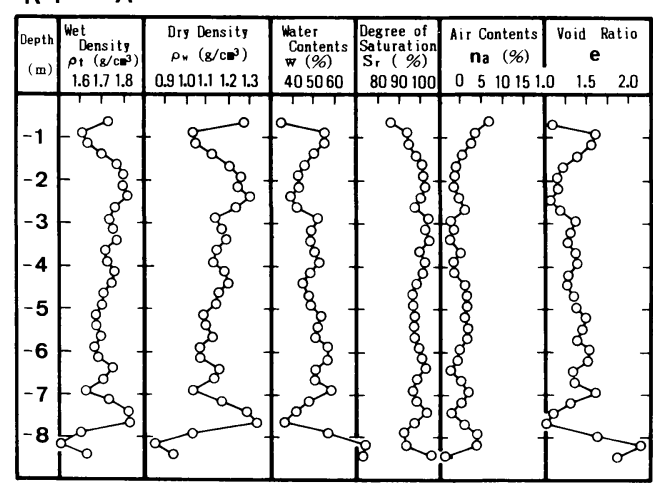

R I - B

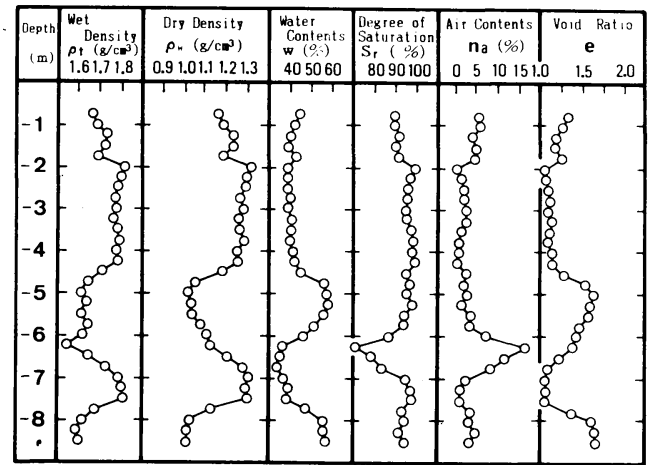

RI - C

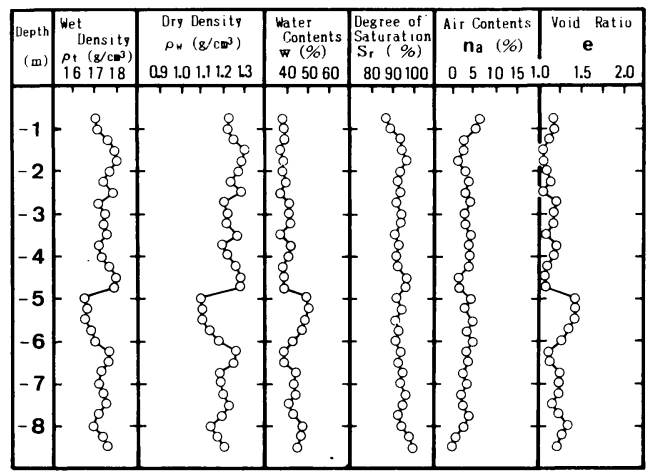

Fig. 17 Results of the Measurement of Density and Water Contents with RI.

改良体の強度との関係を前もって何らかの方法で求める 必要がある. 特に空気や水の存在と強度の関係は, 本工 法において重要な課題として残されるだろう。さしあ たっての利用法としては, 事後ボーリングとの併用が有 効であると考えられる.

\section{（2）改良体に対する仕事量による品質評価 ${ }^{3)}$}

施工中に改良体の均質性を評価する方法として、摜抖 に要した仕事量について検討した。改良体作成中に㹂汼 に要した単位体積当たりの仕事量および単位時間当たり の仕事量（仕事率）を次式により計算し，各深さに対し 

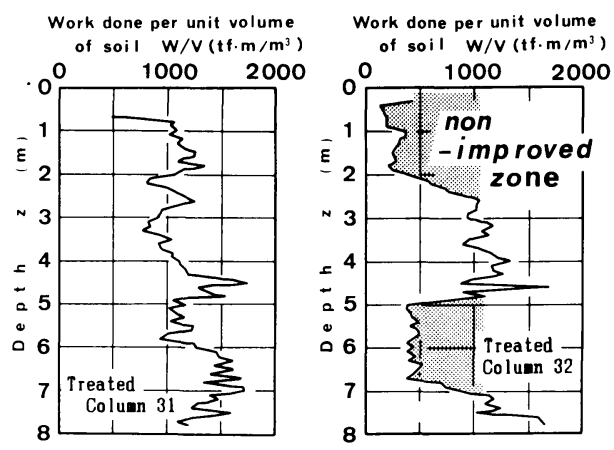

Fig. 18 Work Done for Mixing per Unit Volume of Soil.
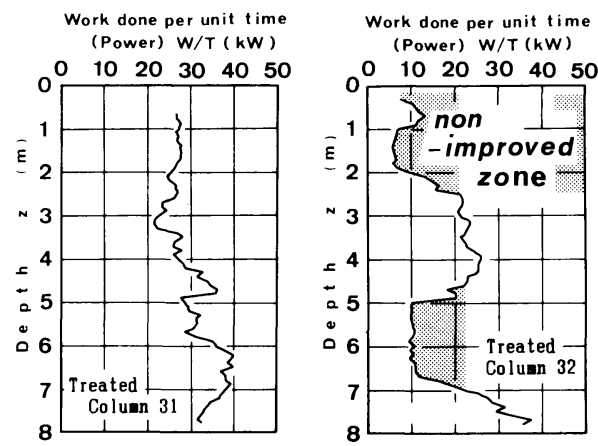

Fig. 19 Work Done for Mixing per Unit Time (Power).

て示したものが Fig.18, Fig.19である.

$$
\begin{aligned}
& \frac{W}{V}=\left(\operatorname{Tor} \cdot 2 \pi r+\operatorname{Res} \cdot \frac{v}{n}\right) / \pi r^{2} \cdot \frac{v}{n} \\
& \frac{W}{T}=\operatorname{Tor} \cdot \frac{2 \pi n}{60}+\operatorname{Res} \cdot \frac{v}{60} \ldots \ldots \ldots \ldots \ldots \ldots
\end{aligned}
$$

ここに, $W$ は仕事量, $V$ は体積, $T$ は時間, Tor $r$ 抵抗モーメント, Res は摜汼翼の貫入抵抗, $r$ は翼径 の $1 / 2, v$ は貫入速さ， $n$ は回転数である.なお改良体 番号 $31 ， 32$ はそれぞれ RI 計測における RI-C, RI-B に対応する.

これらの図をみると，改良体 31 については，全体に わたってほぼ一様な仕事率で施工がなされているが，改 良体 32 では, 樑さ $2 \mathrm{~m}$ より浅い部分と深さ $5 \mathrm{~m} \sim 7 \mathrm{~m}$ のあたりで極端に仕事率が低下していることがわかる.

これは改良材搬送のための空気が十分に回収されずに 残っていること，あるいは改良材の添加がさほど強度の 改善につながらないことなどにより，筧汼翼が土に対し て有効な䚋汼を行うことができなかったことを表わして いると考えられる，つまり改良体 31 は，全体にわたつ て均質な改良体が形成され，改良体 32 については，強 度の弱い部分を有する不均質な改良体が形成されている と解釈することができる。このことは，実際に施工後の 調査によって確認されており，この品質評価の方法が本 工法において有効なものであることがわかった.
以上のように改良体作成中に摫挥翼がなす単位体積あ るいは単位時間当たりの仕事量を計測することで, 施工 中に改良体の均質性すなわち施工精度の評価が可能であ ることがわかった。これにより, 全改良体に対しての評 価を行うことができる.また今回は仕事率が全体にわ たって一様であるかないかの検討であったが, 今後室内 配合試験の摫汼エネルギーと施工現場における計測值の 対比などから，摜汼のメカニズムを含めた定量的な検討 を加えることで, 改良体の強度に対する評価も可能とな ることも十分にうかがえた。

\section{4. おわりに}

以上のように, 深層混合処理工法における施工中の計 測值により, 原地盤の把握および施工精度の確認, 改良 体の品質の評価が可能であることがわかった，本工法の 施工の自動制御化に向けて, 今後はこれらに対する対処 法すなわち原地盤の把握を行った後, だのように改良材 の種類, 配合率, 摫拌条件を設定すればよいのか, また 品質の悪い改良体であると評価された場合に, 次に何を すれば品質の改善につながるのかなどについて検討する 必要がある.

また本工法をただ単に軟弱地盤改良に用いるだけでな く, 改良材の補強材たとえば鋼管や鋼棒などを貫入し, 基礎杭として用いるなど, 本工法のさまざまな用法を検 討し, 本工法の利用価値を高いものにすることも, 今後 に残された興味深い課題である.

謝辞：最後になりましたが, 実験現場を提供して 頂いた新潟県六日町土木事務所の皆様ならびに現場実験 に際して協力を頂いた噴射摫汼工法研究会の皆様, 特に 鈴木昭彦氏に厚く御礼申しあげます。

\section{参 考 文 献}

1）寺師昌明：総説深層混合処理工法, 基礎工, Vol. 13, No. 2, pp. 2 9, 1985.

2) 奥村樹郎：深層混合処理工法の現状と普及化への問題点, 基礎工, Vol. 13, No. 2, p. 1, 1985.

3）畠昭治郎 - 檜垣義雄 - 青井 実・鈴木昭彦：深層混合処 理工法における柱体の早期品質評価法について, 土木学 会第 41 回年次学術講演, 1986.

4）芦田恵樹：筧拌翼による砂の強度特性の推定に関する基 硶的研究, 京都大学卒業論文, 1984.

5）畠昭治郎：深層混合処理装置メカトロニクス化の基礎研 究, 研究報告書, 1985 .

6）畠昭治郎 - 檜垣義雄 - 芦田恵樹 - 青井 実: 回転掘削に おける土質とトルクの関係, 土木学会関西支部年次学術 講演, 1985 .

7）新潟県六日町土木事務所：魚野川筋河川激甚災害対策特 別緊急事業伊田川筋軟弱地盤設計委託, 調査報告書, 1985. 
8）基礎地盤コンサルタンツ：深層混合処理地盤改良地盤の 事前調查 (三成分コーン貫入試験), 調査報告書, 1985.

9）畠昭治郎・檜垣義雄・芦田恵樹・青井 実：深層混合処 理工法における摜拌翼の貫入抵抗と地盤状態との関係, 土木学会第 40 回年次学術講演, 1985.

10）岩井喜八郎：第 3 章オランダ式コーン貫入試験, 土質調 査試験結果の解釈と適用例, 土質工学会編, pp. $91 \sim$
135.

11）畠昭治郎・檜垣義雄・金子義信・青井 実：粉体噴射摫 汼工法 (DJM) におけるRI を用いた軟弱地盤の改良精 度の判定について, 第 22 回土質工学研究発表会, 1986 .

12）ソイルアンドロックエシジニアリング：DJM 工法実験 RI 測定調查, 調查報告書, 1985 .

(1986.4.8 - 受付) 